\title{
研究課題別事後評価結果
}

\section{1.研究課題名 人工光物性に基づ〈新しい光子制御デバイス」}

2. 研究代表者名及び主たる研究参加者名 研究機関名 職名(研究参加期間終了時点) 研究代表者 中野 義昭 東京大学先端科学技術研究センター 教授) 主たる共同研究者

$\begin{array}{ll}\text { 霜垣 幸浩 } & \text { 東京大学大学院工学系研究科マテリアル工学専攻 助教授) } \\ \text { 田中 雅明 } & \text { 東京大学大学院工学系研究科電子工学専攻 教授) } \\ \text { 土屋 昌弘 } & \text { 情報通信研究機構基礎先端部門 主任研究員) } \\ \text { 山下 真司 } & \text { 東京大学大学院工学系研究科電子工学専攻 助教授) }\end{array}$

3.研究内容及び成果

本研究では、半導体材料のマク口な光物性を一原子層単位て設計 制御されたミク口な人結 晶構造によl覑革し、電気光学効果、相互位相変調、四光波混合、磁気光学効果など、広義の光 非線形性を飛躍的に高めること、ならびに、これら半導体人工光物性と半導体分布ブラッグ反射器 やファイバブラック格子鏡で構成される高度な光共振器/干渉計構造に基づいて、デジタル波長 変換器、光 $3 R$ 中継器、光ロジック、光バッファーメモリなどの全光子制御デジタルデバイス/回路 を実現し、デジタルフォトニクスの基礎を築くことによって光情報通信技術の発展に資することを目 指した。

上記目的を達成するために、本プロジェクトでは五つの研究グループを編成して研究を害施した。 第一のグループ 霜垣グループ)は、単原子層 MOVPE／集積プロセス技術の研究」を担当した。 有機金属気相エピタキシャル成長(MOVPE)による化合物半導体結晶成長において、へテロ界面 の急峻性は最も重要なプロセス制御因子である。こでは分光エリプソメトを用いた表面产の場観 察や、作製したへテロ構造のX 線光電子分光(XPS)、二次イオン質量分析(SIMS)などによる組成分 析、透過型電子顕微鏡(TEM)による構造解析などからへテロ界面形成ガス切替シーケンスの最適 化を行った。また、MOVPE 成長層最表面のサブサーフェイスを考慮した界面形成モデルを構築し た。一方シリコン酸化膜をマスクとして用いる面積選択 MOVPE 成長技術に関しても研究を行い、 広幅選択成長の成長速度分布を解析して表面反応速度に関する情報を抽出した、さらに反応器 内のマク口な成長速度分布から製膜分子種の拡散係数に関する情報を得、これらの解析から得た 速度定数を基にして、面積選択成長における組成 膜厚のマスクパターン依存性を精密に予測す ることに成功し、本手法による光集積回路作製用計算機支援設計(TCAD)システム構築が可能で あることを示した。

第二のグループ(田中グループ)は、入工光磁性材料とスピン機能光デバイスの研究」を担当し た。主な成果は、InP基板上にIII- $\mathrm{V}$ 族ベース四元混晶磁性半導体 $[(\mathrm{InGa}) \mathrm{Mn}] A s$ をエピタキシャル 成長することに成功し、弚れがきわめて大きな磁気光学効果をもつ MCD〜400 mdeg) こと、キュリ 一温度は $130 \mathrm{~K}$ に達することを示したことである。また、GaAs:MnAsナノクラスタ一構造と光の多層 膜の関連では、GaAs中にMnAsナノクラスターか埋め込まれた構造を形成し、光の構造や物性制 御に成功し、III- V 族半導体へテロ構造との整合性がきわめて良好であることを示したこと、MnAs 微粒子サイズが 10nm 以下では室温では超常磁性、10nm 以上では強磁性的振る舞いを示すこと を明らかにしたこと、室温で大きな磁気光学効果 ワァラデー回転角 $0.4-0.8 \mathrm{deg} / \mu \mathrm{m})$ を得たこと、 GaAs:MnAsナノクラスターとGaAs/AIAs 多層膜分布ブラッグ反射鏡(DBR)を組み合わせた多層膜 を形成し、所望の波長の光を GaAs:MnAs 磁性層に閉じこめることによって、透過て磁気光学効果 がきわめて大きくなることを示したこと、GaAs:MnAs クラスターを用いた半導体導波路型光アイル 一夕の提案、解析を行ったことも重要な成果として挙げられる。

第三のグループ(中野グループ)は、入工光物性に基づくデジタル光デバイスの研究」を担当し た。具体的には、量子井戶電界吸収光非線形性を利用した全光制御デバイス、MOVPE による AIN/GaN 多重量子井戶サブバント間遷移全光スイッチ、量子構造を利用した半導体レーザの制 御、全光論理ゲーの試作開発、全光フリップフロップの試作開発、半導体能動導波路型光アイソ 
レータの提案と試作、の各項目につき研究を行つた。乥の結果得られた主要な成果は、MOVPE窒 化物サブバン間遷移で世界最短波長 $(2.3 \mu \mathrm{m})$ を得たこと、ICP エッチングによる低損失なハイメ サ光導波路の作製に成功したこと、半導体光アンプ(SOA)集積マッハツェンダー干渉計型全光論 理ゲート関連して、一回のMOVPE選択成長による作製に成功したこと、試作素子において消光 比 20dB の全光スイッチ動作を得たこと、スイッチングウインドウ28ps の高速動作特性を実証したこ とである。さらに、方向性結合器(DC)および多モード干渉結合器(MMI)双安定半導体レーザ型全 光フリップフロップに関連して、全光セットセッッフリップフロップ動作に成功したこと、 - 10〜 OdBm の低エネルギー動作が得られたこと、同素子を用いて 10ns から 200ns へのビッ悵変換動作実証 を行ったこと、が挙げられる。また，半導体能動導波路型光アイソータに関連して、半導体導波 路における非相反損失シフけ観測に成功したこと、光アイルータプロトタイプの試作を行いさ $1 \mathrm{kG}$ の磁場印加で $9.3 \mathrm{~dB} / \mathrm{mm}$ の非相反損失を得たこと、か特筆すべき成果と言える。

第四のグループ(土屋グループ)は、光物理と光システムの研究」を旨とし、他グループで行なわ れているデバイス試作研究や物性研究に対して、システム応用的見地から指針を与えることを目 的とした。具体的には、超短光パルスの発生とDWDM 通信への応用、顕微ラマン分光法による光 通信用光素子および材料の解析、モート同期半導体レーザの物理と応用、電気光学 磁気光学 プローブを用いたマイクロ波・ジ波回路計測技術、光ファイバ内パラメトリク過程の解明と応用、 光ファイバ無線技術、シリコンフォトニクス、の各項目について研究を行い所期の成果を得ている。

第五のグループ(山下グループ)は、光ファイバハイブリッドデジタル光デバイスとシステム応用」 を担当した。高効率·広帯域光ファイバ波長変換器を研究し、信号光にも励起光と同期した変調を かける同期位相変調法とい新しい波長変換技術を発明した。また、ファイバーブラッググレーティ ング(FBG)を用いて1つの位相変調器を双方向て使 澵しい構成を提案した。超広帯域 高密度光 ファイバグレーティングの研究では、グレーテイングが書き込まれていない部分に一樣な紫外(UV) 光を照射して多点位相シフ FMPS)を与えることにより 数 cmの長さのままでSSFBG を高密度化す る画期的な技術を開発した。さらに、UV 光照射の代わり熱光学効果を利用することにより可変に する研究も行った。他方、全光型半導体再生中継器に関しては、半導体レーザの注入同期現象 の閾値を調節することにより、波形が劣化した強度変調光を波形か等化された周波数変調光に変 換し、さらに狭帯域光フィルタにより波形が等化された強度変調光を得ることに成功した。また高速 化を狙於めに、2サイドモード注入同期法を提案し、実験により5Gb/s のランダムパターン信号の 波形整形に成功した。多波長光ファイバレーザに関しては、波長間隔が可変な多波長 Er ドープ光 ファイバレ一ザを開発した。また短パルス発生のためにモー恫期技術と多波長技術とを組み合わ せて、多波長モー恫期光ファイバレーザを実証した。最後に、カーボンナノチューブ(CNT)を用 いたモート同期光ファイバレーザの研究を行い、利得か非常に高い光ファイバ 長さ $2 \mathrm{~cm})$ と、高反 射光ファイバミラーとの組み合わせにより高繰り返し周波数( $5 \mathrm{GHz}$ )受動モート同期光ファイバ レーザを実現した。

本プロジェク恮体を通じて、スケーラブルなフォトニックネットワークを構筑するために必須のデ ジタル光デバイス、即ち光論理ゲート、光フリップフロップ、集積化光アイルータの開発に目途が 立ち、デジタルフォトニクスの基礎か涸められたと言える。

\section{4.事後評価結果}

4-1.外部発表(論文、口頭発表等)、特許、研究を通しての新たな知見の取得等の研究成果の状況

論文発表は英文103件、和文11件、炎のうち招待されたものが夫々5件、1件、口頭発表(ポスタ 一発表含む)は国際会議258件、国内会議256件、光の沼捛されたものが夫々43件、11件、特 許出願は国内11件、海外5件なと国際的評価の高い学会誌や国際会議に多くの優れた研究成 果か発表されてお以下記は弚の中でも特筆すべきもので、いずれも世界で初めて報告された独 創的な成果である。

(1) 人工光物性を実現するための単原子層MOVPE技術や集積プロセス技術及びTCADの作 成

(2) MnAsをGaAs中に分散させた磁性半導体の研究とスピノ光機能デバイスの研究

(3) 光デジタルエレクトロニクスの基本デバイスである全光論理ゲート 全光フリップフロップ、半 
導体光アイルータを実現

(4) 4次の光非線形性を用いて超短光パルスの発生、超高帯域パラメトリ以利得の実現

(5) 高効率·広帯域光ファイバ波長変換器、超高帯域高密度光ファイバグレーテインク等の実現

4-2.成果の戦略目標 科学技術への貢献

本研究チーム成果の戦略目標 入工光物性に基づく新しい光子制御デバイス」及び科学技術へ

の貢献は下記の4点に要約することができる。

(1) MOVPEにおけるマスクの影響の実験的検証と結晶成長モデルの作成により MOVPE技術 の発展に大きな貢献をし、更に多層構造作成の際の界面急峻性を改善するMOVPE法の 確立による技術的インパクト。

(2) III- V 族強磁性半導体(InGaMn)Asを創成し、III- V 族半導体と光の多層膜中にMnAs 強磁性 ナ粒子を析出させ光れによる磁気光学特性を示した研究の科学的技術インパクト。

(3) 全光論理デバイス、全光フリップフロップ、光アイルータの3基本デバイスの実現による 技術的インパクト。

(4) オプティカルファイバの特性を生かした増幅器、フィルタ、レーザの実現等の技術的インパク 快。

\section{4- 3.との他の特記事項 受賞歴など)}

人工光物性としては III- V 族半導体の band- structure engineering だけでなく磁性半導体や光フ アイバ、カーボンナチューブも含めて多樣な特性を対象として全光論理ゲート 全光フリップフロ ップ、光アイルータ等デジタル光エレク吅ニクスの基本デバイスの他、パラメトック増幅器やフィ ルタを実現しており，所期の計画を達成し国際水準を越える研究成果をいくつも上げた。スピ機 能デバイス、非線形光学素子などのデジタルフォトニクスへの応用はこれからの課題で、大きな発 展が予測され、カーボンナノチューブを使用した短光パルスの発生等光ファイバを利用した新技 術は企業化か期待できる。

本研究はデジタル光ネットワークの実現のため光デジタルデバイスの研究であるから、常にシス テム構成上、デバイス特性に要求される条件を勘案しながら、デバイスの研究を進めていく事は当 然であるが、一方全〈新規なデバイスの発明により、現在想定されているデジタル光ネットワークと は全〈異なるネットワーク構成の可能性探求も等閑視してはならない。

デジタルフォトニクスの実現は、所謂ITバブルの崩壊で産業界での研究開発がやや低調な状況 の中で、大学が将来に向けた基礎的研究を続ける意義は大きい。

受賞に関しては以下の通りである。

応用物理学会講演奨励賞、2001年3月、清水大雅 猜水大雅口田中雅明口安藤功兒 半導体べ一 ス1次元磁性フォトニック結晶における磁気光学特性の改善」2000年9月秋季第61回応用物理学 会]

·日本応用磁気学会 学術奨励賞 武井賞)、2001年9月、清水大雅 请水大雅、宮村信、田中雅 明 半導体ベース磁性フォトニック結晶」、2000年9月日本応用磁気学会第24回学術講演会 ナノ. メラ゙スコピック磁性体の構造と機能」シンポジウム]

丸文研究奨励賞 丸文研究交流財団)、2002年3月、田中雅明、半導体スピンエレクトロニクスに 向けた複合エピタキシャルへテロ構造の創製」に関する研究業績。

応用物理学会講演奖励賞、2003年3月、竹中充 竹中充、中野義昭 方向性結合器双安定レ一 ザ構造を有する半導体全光フリップ・フロップの実現」、2002年9月秋季第63回応用物理学会]

第17回 日本 IBM科学賞」、2003年11月、田中雅明、磁性体/半導体へテロ構造のエピタキシャ ル成長とスピンエレクトロニクスへの展開に関する研究業績

応用物理学会講演奨励賞、2004年3月、C. カントウンキッティクル チャイヤシットカントウン キッティクル、脇一太郎、霜垣幸浩、中野義昭 MOVPE成長AIN/GaN多重量子井戶における1.55

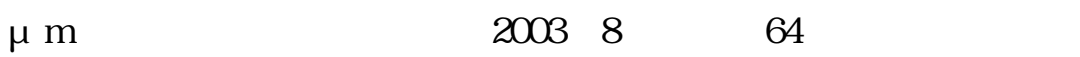

・・゙ンアウォード(米Materials Research Society), 2004年12月，清水大雅

H.Shimizu and Y.Nakano, "Fabrication of a TE mode semiconductor- waveguide- type optical 
isolator based on the nonreciprocal loss shift", Abstracts, MRS Fall Meeting, J4.7, p. 276, Boston, Massachusetts, November 29- December 3, 2004. 